\title{
Special Issue "Reclamation of polluted soils for food production and human health: part 1 "
}

\author{
Jaume Bech
}

Published online: 4 May 2021

(C) The Author(s), under exclusive licence to Springer Nature B.V. 2021

\section{Background}

This collection of papers submitted to this Special issue is mainly an outgrowth from the Session SSS8.2. EGU 2019 "Soils under industrial and agricultural impact and their improvement to enhance the quality of food production and human health", Vienna, April 2019.

Soils are the basis of terrestrial ecosystems and crossroad of biogeochemical cycles at the lithospherehydrosphere-biosphere-atmosphere interface. Soils are limited and vulnerable resource, and soil quality must be preserved. Soil is subjected to physical and chemical degradation and needs reclamation. To survive and develop as species, humans should short-term decisions and use scientifically based approaches to find a stable existence in a changeable noosphere. Humankind should optimize the ecogeochemical state of anthropized soils, improve the quality of agricultural and forestry production and finally human health in conditions of man-made contamination.

This Special Issue contains 17 papers written by authors from 15 countries: Brazil, Chile, China, Egypt, Finland, Germany, Hungary, India, Iran, Mexico, Myanmar, Nigeria, Pakistan, Russian Federation and Turkey.

J. Bech $(\bowtie)$

University of Barcelona (UB), Barcelona, Spain
This collection of papers is mainly focused on eight topics:

1. Soils close to mining, quarries, smelters, power stations, chemical plants and industrial areas.

2. Remediation of oil-contaminated soils.

3. Toxic elements in soil-plant interactions.

4. Wastewaters.

5. PAHs.

6. Urea fertilizer.

7. Chelating effect.

8. Nanoparticles.

In the following paragraph, I will summarize the content and main results of these papers published in this Special Issue.

\section{Research topics}

Soils close to mining, quarries, smelters, power stations chemical plants and industrial areas

There are eight papers in this Special Issues dealing with the topic, soils close to mining, quarries, smelters, power stations, chemical plants and industrial areas:

Montofré et al. (2021) evaluated poultry waste and ammonium nitrate for to condition and stabilize a copper mine tailing and help to vegetation cover settle. Ammonium nitrate was tested as a $\mathrm{N}$ source and chicken bone ash a $\mathrm{P}$ source. The authors used soil columns from the area to be remediated for 
determinate the mobility and availability of metals and nutrients by analyzing their leachates chemically. Results showed that the use of chicken bone ash decreases soluble metal concentrations, especially in $\mathrm{Fe}$ and soluble $\mathrm{Mn}$. The use for fertilization of two evaluated amendments does not imply phytotoxicity risks. Therefore, the two evaluated amendments are effective for both fertilization and phytoremediation.

Labastida et al. (2021) studied the feasibility of remediation by means of EDTA of an agricultural calcareous soil polluted with $\mathrm{Pb}$ of nearby mine tailings in Zimapan, Mexico. Total geoavailable and bioaccesible concentrations in the gastric and intestinal phases were determined to evaluate $\mathrm{Pb}$ availability and health risk. Soil was then washed with EDTA and analyzed by geochemical fractionation, and the impact on the mesophile bacteria and fungi/yeast was analyzed. Results showed total $\mathrm{Pb}$ concentrations up $46 \%$ bioaccesible fraction in the gastric phase and $12 \%$ bioaccesible fraction in the intestinal phase indicating a health and environmental risk. Geochemical fractionation showed that most $\mathrm{Pb}$ is associated with $\mathrm{Fe} /$ Mn oxi/hydroxides. The soil microbiology was modified by EDTA, with an increase in anaerobic bacteria and decrease in fungi/yeast populations. Therefore, this is a feasible technique for in situ remediation of calcareous soils polluted by $\mathrm{Pb}$.

Feng X et al. (2021) used Landsat images from 1991 to 2018 in the Lingbei mining area of Dingnan County, China, to construct a rare earth remote sensing ecological index (RE-RSEI) based on five indicators of greenness, heat, wetness, desertification and soil erosion, to assessment of the environment status during mining area development analyzed from a pixel-level perspective. The results show that since 1991, due to the mining techniques of pond leaching and heap leaching and the soil condition, mining has caused severe damage to the ecological environment quality of the mining area in which RE-RSEI value dropped from 0.744 to 0.675 . After 2010, through the improvement the mining technology the ecological environment was slowly restored toward sustainable development.

Sasmaz et al. (2020) investigated the translocation and accumulation of Sr by the terrestrial and aquatic plants affected by mining and municipal wastewaters around Elazig, Turkey. Plants and their soil samples were collected, and $\mathrm{Sr}$ values were analyzed by ICPMS. The enrichment coefficients of roots (ECR) and shoots (ECS) and translocation factors (TLF) of studied plants were calculated, and according the values of these coefficients, the plants were divided into three groups: a) candidate plants (ECR and ECS $<1)$ Salix Sp., Tamarix tetranda; b) good plants (ECR and $\mathrm{ECS} \simeq 1$ ) Phragmites sp. and Xantium; (c) the best plants (ECR and ECS > 1) Typha latifolia, Bolboscholnus ascbersus, Lythnium salicaria. These results showed that (b) and (c) plant groups had high ability to accumulate $\mathrm{Sr}$ to plant for their soil and therefore may be useful for rehabilitation soils contaminated by Sr.

Ediagbonya et al. (2019) investigated the effect of quarry activities on Pennisetum purpureum leaves and soils around Onigambari Forest Reserve, Oyo State, Nigeria. Soil and leaves samples were collected from two different distances from the quarry plant (Sites 1 and 2). The elements in samples were determined using proton induced $\mathrm{x}$-ray emission. Their concentration in soil samples from site 1 was higher in $\mathrm{Mg}$, $\mathrm{Cl}, \mathrm{Ca}, \mathrm{Ti}, \mathrm{Cr}, \mathrm{Mn}, \mathrm{Fe}, \mathrm{Zn}$ and $\mathrm{Zr}$ than site 2 and the control site. In the leaves, the authors found similar values, except for $\mathrm{Cd}$ and $\mathrm{Ag}$, that were highly enriched. $\mathrm{Si}$ and $\mathrm{Fe}$ concentrations in soil samples from the Onigambari forest reserve were found to be very high, while $\mathrm{Ag}$ and $\mathrm{Pb}$ were very low. The mean concentration of $\mathrm{Fe}$ and $\mathrm{Ti}$ in $P$. purpureum leaves from the Onigambari forest was also very high, while $\mathrm{Pb}$ was very low.

Minkina et al. (2020) assessed the environmental and human health risk of potentially toxic elements (PTEs) contamination in soils around the Novocherkassk Power Plant (NPP), Southern Russia. The impact zone of NPP is $7 \mathrm{~km}$ down wind of prevailing winds. The spatial patterns of soil pollution are very influenced by of local atmosphere circulation, while the soil properties in the study area play a secondary role. The highest concentrations of PTEs exceeded the regional background and health standards within a radius of $3 \mathrm{~km}$ to the west of the NPP, which corresponds to a zone of soils contaminated with $\mathrm{Cr}$, $\mathrm{Ni}, \mathrm{Cu}, \mathrm{Zn}, \mathrm{Cd}$ and $\mathrm{Pb}$. The health risk assessment indicates no carcinogenic risks of adults and low risk of children.

Nevidomskaya et al. (2020) studied the validity of $\mathrm{BCR}$ sequential extraction of $\mathrm{Zn}$ and $\mathrm{Cu}$ of the highly contaminated Technosol near of chemical plant (Severskii Donets River floodplain, southern Russia) based on the XAFS and XRD analyses after each stage of 
extraction. In the residual soil left over the first and second fractions, the $\mathrm{Zn}-\mathrm{S}$ bond appeared as würtzite more than $50 \%$, while the $\mathrm{Cu}-\mathrm{S}$ bond was almost completely represented only by chalcocite $\left(\mathrm{Cu}_{2} \mathrm{~S}\right)$. The XRD analysis revealed the presence of sphalerite, würzite, covellite and bornite. SEM data confirmed that würzite was the dominant, whereas the $\mathrm{Cu}-\mathrm{O}$ bond was dominant in the residual fraction. The methodology used revealed the incomplete selectivity of the extractants in the extraction of $\mathrm{Zn}$ and $\mathrm{Cu}$ in long term highly contaminated soils.

Kovács-Bokor et al. (2020) investigated the toxic metal phytoextraction of Sinopis alba L.,Lolium perenne L., Pisum sativum L. var. Rajnai törpe and Raphanus sativus L. var. Szentosi óriás vaj in a field experiment along the river Danube, close an industrial town Dunaúj-város, Hungary. Soil/sediment and plants (leaves, stems and roots) were assessed for the contamination of $\mathrm{Cd}, \mathrm{Ni}, \mathrm{Cu}$ and $\mathrm{Zn}$. Results showed that $\mathrm{Cd}$ and $\mathrm{Ni}$ concentration was below while $\mathrm{Cu}$ and $\mathrm{Zn}$ exceeded the Hungarian permissible limits. Bioconcentration factor (BAF) was $<1$, in the shoot plants, in order: $\mathrm{Cu}>\mathrm{Zn}>\mathrm{Cd}>\mathrm{Ni}$. The transformation factor (TF) in plants was $>1$. For $\mathrm{Cu}$ and $\mathrm{Zn}$, $\mathrm{Cd}$ was translocated into the leaves of R. sativus. The potential human daily intake of metals (DIM) was $<1$ for adults and children. Health risk index (HRI) values for children were $>1$ for $\mathrm{Cd}$ in $\mathrm{R}$. sativus and for $\mathrm{Zn}$ and $\mathrm{Cu}$ in $\mathrm{P}$. sativum.

\section{Remediation of oil-contaminated soils}

There are two papers in this Special Issue refer to the second topic, remediation of oil-contaminated soils.

Bykova et al. (2020) researched the properties of oil-contaminated soil in 3 landscapes: the permafrost treeless Arctic ecosystem, boreal forest and temperateclimate grassland-woodland ecotone. Laboratory studies showed that the concentration of petroleum in soils being 2-25 times higher than the permissible content of them $(1000 \mathrm{mg} / \mathrm{Kg})$. The authors applied thermal effects for the oil products desorption from the soil and found that the optimal regime of the treatment temperature was from 25 to $250{ }^{\circ} \mathrm{C}$. This processing temperature is lower than the combustion point of all humates $\left(450{ }^{\circ} \mathrm{C}\right)$. The conducted experimental studies deal with an eco-friendly solution for the implementation of thermal desorption treatment of oil- polluted soils, preserving the soil fertility and avoiding the need to expensive transfer oil-polluted soils for disposal.

Bakina et al. (2020) studied possible scenarios of bioaugmentation due to application of oil-degrading bacteria preparations for remediation of oil-contaminated podzolic soil in a long-term field experiment. Of the five bacterial preparations studied, one had a positive effect on soil biological activity and oil mineralization processes; two preparations had weaker influence and two more had a negative impact. All preparations were noneffective during the latter stages of long-term remediation processes. Therefore, the successful application of bioaugmentation for the restoration of oil-contaminated soil requires testing of environmental safety of bacterial preparations in a long-term field experiments prior to treatment processes.

\section{Potential toxic elements in soil-plant interactions}

Two papers of this Special Issue cover the third topic, potential toxic elements in soil-plant interactions.

Deng et al. (2019) studied the concentration of PB, $\mathrm{Cd}, \mathrm{Hg}$ and $\mathrm{As}$ in vegetables and soils of Chongquing, China, as well the correlation between them. Results show that the concentration of potential toxic elements (PTE) in different vegetable bases of Chongquing is significantly different. The order of PTE pollution in vegetables is: $\mathrm{As}>\mathrm{Cd}>\mathrm{Hg}>\mathrm{Pb}$. The concentration of $\mathrm{Cd}$ and $\mathrm{Hg}$ in leaf vegetables is significantly higher than that of other vegetables; the concentration of $\mathrm{Pb}$ and $\mathrm{As}$ in root vegetables is significantly higher than that other vegetables. The variation coefficients of $\mathrm{Pb}, \mathrm{Cd}$ and $\mathrm{As}$ concentrations are relatively higher, among which the variation coefficient of $\mathrm{Cd}$ concentration is the highest in Solanaceous vegetable, and the variation coefficient of $\mathrm{Hg}$ concentration is the highest in root vegetable. Significant positive correlation was found between the $\mathrm{Cd}$ concentration in vegetables and the $\mathrm{Cd}$ concentration in soil. There was no significant correlation between the concentration of $\mathrm{Pb}, \mathrm{Hg}$ and As in vegetables and $\mathrm{Pb}, \mathrm{Hg}$ and $\mathrm{As}$ in soil.

Zhang et al. (2020) investigated the source identification of soil elements and risk assessment of trace elements under different land uses on the Loess Plateau, China. Authors collected topsoil samples from two sub catchments in the Liudaogou watershed 
that included four land-use types: bare land (BL), forestland (FL), grassland (GL) and check-dam (CDL). Results showed moderate spatial variation in the soil elements. The mean concentration of: $\mathrm{Cu}, \mathrm{K}$, $\mathrm{Mn}, \mathrm{Na}$ and $\mathrm{Zn}$ in the land-use types researched exceeded the soil background values. In subcatchment 1, there exists a high homology between $\mathrm{Cu}$ and $\mathrm{Mn}$, mainly originated from coal mines and smelters. $\mathrm{Zn}$ and $\mathrm{K}$ derived from fertilizers and sewage sludge. In subcatchment 2, $\mathrm{Cu}, \mathrm{K}, \mathrm{Mg}, \mathrm{Na}$ and $\mathrm{Zn}$ are originated from mining and smelting plants, fertilizers and sewage. $\mathrm{Ca}$ had high homology with $\mathrm{Fe}$ in both subcatchments. The values of the pollution index suggest moderate pollution in FL, GL and CDL.

\section{Wastewaters}

One paper in this Special Issue refers to the fourth topic, wastewaters.

Natasha et al. (2020) evaluated the effect of coapplication of wastewater and freshwater on the physiological properties and trace elements (TEs) content in Raphanus sativus in Distric Vehari, Pakistan. Results showed all the treatments were unfit for $R$. sativus irrigation due a TEs at concentrations above toxic limits, mainly $\mathrm{Cd}$. The concentration of $\mathrm{Cd}, \mathrm{Fe}$ and $\mathrm{Mn}$ in soil exceeded their limit values for all the treatments. Application of all the treatments caused high uptake and accumulation of $\mathrm{Cd}, \mathrm{Cu}, \mathrm{Fe}, \mathrm{Ni}, \mathrm{Pb}$ and $\mathrm{Zn}$ in the edible part of $R$. sativus which can pose serious health risks. The TW irrigated treatments (tube-well water + wastewater and canal water) caused more variation in physiological attributes than other treatments due to high TEs contents. It is highly necessary to monitor the suitability of irrigation waters for vegetables.

\section{PAHs}

One paper in this Special Issue refers to the fifth topic, PAHs.

Sushkova et al. (2020) determined the concentrations of PAHs concentration effect on the cellular and subcellular changes of Phragmites australis in the zone of industrial sewage tanks and sludge reservoirs in Kamensk-Shakhtinsky, Rostov region, Southern Russia. The PAHs concentration in soil monitoring sites in impact zone was significantly higher (30 times) than those in monitoring site. The maximum accumulation was found for phenanthrene and chrysene. The effects of PAHs pollution on changes of cellular and subcellular organelles of P. australis such as: significant changes in the peripheral parts of the root, enhancement in the optical density, compaction of chlorenchyma cells, disturbance in the integrity of the tonoplast, the contents of the cytoplasm were found to penetrate the central vacuole, and other destructive changes in cellular and subcellular organelles.

\section{Urea fertilizer}

One paper in this Special Issue covers the sixth topic, urea fertilizer.

Zhran et al. (2019) studied the effect of urea fertilization on Vicia faba L. under various Ni levels with or without acetic acid addition, using $15 \mathrm{~N}$ labeled fertilizer. A pot experiment was set up for this study. $15 \mathrm{~N}$-labeled urea was added at three doses. NiSO4 was also applied at three levels in soil. Treatment with the addition of $60 \mathrm{mg} \mathrm{N}+50 \mathrm{mg}$ $\mathrm{Ni}$ showed the highest values in root and shoots, $\mathrm{N}$-uptake by shoots, $\mathrm{N}$ derived from fertilizer (Ndff\%) and $\mathrm{N}$ use efficiency (NUE) by shoots in both with and without acetic acid solution. Higher rate of $\mathrm{Ni}$ addition can decrease shoot and root biomass by inhibiting the ability of the plant to uptake the $\mathrm{N}$ efficiently. But an addition of acetic acid solution induced the improvement in NUE\% and Ndff\% by shoot and root of V. faba L.

\section{Chelating effect}

One paper in this Special Issue refers to the seventh topic, chelating effect.

Rocha et al. (2019) determined the chelating effect and antioxidant activity of pyrogallol, as well evaluated its cytoprotective in prokaryotic and eukaryotic models against mercury chloride through FTIR analysis. Antioxidant activity was determined by DPPH. Pyrogallol did not confer cytoprotection against toxic $\mathrm{HgCl} 2$ action to the tested bacteria and fungi models used. However, it caused cytoprotection of the plant model, Lactuca sativa allowing better growth and development of caulicles and radicles at certain 
concentrations. It is significant that the pyrogallol showed both an oxidant and Fe chelating activity, which may account for the plant model cytoprotection observed.

\section{Nanoparticles}

One paper in this Special Issue refers to the eight and last topic, nanoparticles.

Rajput et al. (2019) monitored the effects of bulkand nano- $\mathrm{CuO}$ on barley (Hordeum sativum L.) in hydroponic conditions. Results showed no significant differences on studied indicators of barley under low application dose of bulk and nano-CuO. Low concentration of bulk and nano did not affect germination as compared to the control. At high concentration, bulk and nano- $\mathrm{CuO}$ negatively affected the radicle and plumule growth, plant height, root lengths and the anatomy of $\mathrm{H}$. sativum. The metal content increased several times in shoots and roots of $\mathrm{H}$. sativum as a result of nano- $\mathrm{CuO}$ exposure, but the changes in the morphometric parameters of $\mathrm{H}$. sativum were much more pronounced in bulk-CuO treatment. The anatomical observations showed the adverse effects of bulkand nano $\mathrm{CuO}$ on inner structure of $\mathrm{H}$. sativum cell.

\section{Conclusions}

The subject of the Part 1 of this Special Issue is of great importance and 17 papers cover significant aspects of fundamental theoretical and applied research in reclamation of contaminated soils for food production and human health and providing advances to existing knowledge.

Acknowledgements I would firstly to thank the Co-guest Editors Profs. Drs. Elena Korobova, M.Manuela Abreu, Wenhui Qiu and Erika Santos for they valuable collaboration. Moreover, I would like to thank the authors for their contributions and for their patience with the reviewing process as well the reviewers for their observations. Their efforts have improved the quality of this Special Issue. I am extremely grateful to Prof. Dr. Ming Hung Wong Editor-in-Chief of EGAH, Karthick Govindaraju, Production Editor, Suganya Manoharan, Production Editor, Ms. Sherine Joseph, Handling Editor and Ms. Suganya Gunasekar JEO Assistant. Help with English from James Dove and IT assistance from Oriol Bech is also greatly appreciated. Without whose knowledge and experience, this Special Issue could never have been published.

\section{References}

Bakina, L., Chugunova, M., Polyak,Y., Mayachkina, N., Gerasimov, A. (2020). Bioaugmentation: possible scenarios due to application of bacterial preparations for remediation for oil-contamination soil. This Special Issue.

Bykova, M.V., Alekseenko, A.V., Pashkevich, M.A., Drebensted, C. (2020). Thermal desorption treatment of petroleum hydrocarbon contaminated soils of tundra, taiga, and forest steppe landscapes. This Special Issue.

Deng, J., Li, W., Xu, W., He, Z., \& Tan, X. (2019). Correlation and the concentrations of $\mathrm{Pb}, \mathrm{Cd}, \mathrm{Hg}$ and As in vegetables and soils of Chongquing. . China.

Ediagbonya, T. F., Ogunjobi, J., \& Olutayo, O. (2019). Effect of quarry activities on selected biological resources around quarry site within Onigambari forest plantation, Oyo State. . Nigeria.

Feng, X., Hengkai, L., Yingshuang, L. (2020). Ecological Environment Quality Evaluation and Evolution Analysis of Rare Earth mining area under different disturbance conditions. This Special Issue.

Kovács-Bokor, E., Domokos, E., Biró, B. (2020). Toxic metal phytoextraction potential and health-risk parameters of some cultivated plants when grown in metal-contaminated river sediment of Danube, near an industrial town. This Special Issue.

Labastida, I., Mercado, L.A., Rojas, S., Barrera F.B., Beltrán M., Armienta, M.A., Lara, R.H., Luna, R.M. (2020). Remediation by means of EDTA of an agricultural calcareous soil polluted with $\mathrm{Pb}$. This Special Issue.

Minkina, T., Konstantinova, E., Bauer, T., Mandzhieva, S., Sushkova, S., Chaplygin, V., Burachevskaya, M., Nazarenko, O., Kizilkaya, R., Gülser, C., Maksimov, A. (2020). Environmental and human health risk assessment of potentially toxic elements in soils around the largest coalfired power station in Southern Russia. This Special Issue.

Montofré, I., Lam, E.J., Ramirez, Y., Gálvez, M.E. (2019). Evaluation of copper tailing amendments through poultry waste and ammonium nitrate. This Special Issue.

Natasha, N., Shahid, M., Sardar, A., Anwar, H., Khalid, S., Shah, S.H., Shah, A.H., Bilal, M. (2019). Effect of coapplication of wastewater and freshwater on the physiological properties and trace elements content in Rhaphanus sativus: soil contamination and human health. This Special Issue.

Nevidomskaya, D., Minkina, T., Soldatov, A., Bauer, T., Shuvaeva, V., Zubavichus, Y., Trigub, A., Mandzhieva, S., Dorovatovskii, P., \& Popov, Y. (2020). Speciation of Zn and $\mathrm{Cu}$ in Technosol and evaluation of a sequential extraction procedure using XAS. . XRD and SEM-EDEX analyses.

Rajput, V.,Chaplygin, V., Gorotsov, A., Fedorenko, A., Azarov, A., Chernikova, N., Barakhov, A., Minkina, T., Maksimov, A., Mandzhieva, S., Sushkova, S. (2019). Assessing the toxicity and accumulation of bulk- and nano-CuO in Hordeum sativum L. This Special Issue.

Rocha, J.E., Guedes, T.T.A.M., Bezerra, C.F., Costa, M. d.S., Campina, F.F.,de Freitas, T.S., Sousa, A.K., Sobral Souza, C.E., Silva, M.K.N., Lobo,Y.M., Pereira-Junior, F.N., da Silva, J.H., Menezes, I.R.A., Teixeira, R.N.P., Colares, 
A.V., Coutinho,H. (2019). FTIR analysis of Pyrogalol and phytotoxicity-reductive effect against mercury chloride. This Special Issue.

Sasmaz, M., Senel, G. U., \& Obek, E. (2020). Strontium accumulation by the terrestrial and aquatic plants affected by mining and municipal wastewaters (Elazig. . This Special Issue.

Sushkova, S., Minkina, T., Tarigholizadeh, S., Rajput, V., Fedorenko, A., Antonenko, E., Dudnikova, T., Chernikova, N., Yadav, B.K., Batukaev, A. (2020). Soil PAHs contamination effect on the cellular and sub-cellular organelle changes of Phragmites australis Cav.
Zhang, X., She, D., Wang, G., \& Huang, X. (2020). Source identification of soil elements and risk assessment of trace elements under different land uses on the Loess Plateau. . China.

Zhran, M., Moursy, A., Lynn, T.M., Fahmy, A. (2019). Effect of Urea fertilization on growth of Broad bean (Vicia faba L.) under various Nickel (Ni) levels with or without acetic acid addition, using 15N-labeled fertilizer. This Special Issue.

Publisher's Note Springer Nature remains neutral with regard to jurisdictional claims in published maps and institutional affiliations. 